TTR

Traduction, terminologie, re?daction

\title{
Translation, Systems and Research: The Contribution of Polysystem Studies to Translation Studies
}

\author{
José Lambert
}

Volume 8, numéro 1, 1er semestre 1995

Orientations européennes en traductologie

URI : https://id.erudit.org/iderudit/037199ar

DOI : https://doi.org/10.7202/037199ar

Aller au sommaire du numéro

\section{Éditeur(s)}

Association canadienne de traductologie

ISSN

0835-8443 (imprimé)

1708-2188 (numérique)

Découvrir la revue

\section{Citer cet article}

Lambert, J. (1995). Translation, Systems and Research: The Contribution of Polysystem Studies to Translation Studies. TTR, 8(1), 105-152.

https://doi.org/10.7202/037199ar

\section{Résumé de l'article}

Traduction, systèmes et recherche : contribution des études polysystémiques à la traductologie — L'objectif de l'article n'est nullement d'étudier la théorie du polysystème ou les recherches polysystémiques pour elles-mêmes, mais bien plus de déterminer en quoi et comment le PS a exercé une influence dans le développement d'une discipline nouvelle, à savoir les recherches sur la traduction. La position ambiguë des recherches polysystémiques est due à leurs ambitions sur le plan de l'interdisciplinarité, mais aussi à la nécessité de fonctionner au sein d'un monde réel où l'institutionalisation est inévitable sinon même une nécessité. Le point de départ de la théorie du PS n'est point la traduction, mais bien plus l'ensemble des fonctions dynamiques remplies par les traductions dans les cultures et les sociétés, censées être hétérogènes par définition. C'est sur la base d'hypothèses de ce genre qu'un riche panorama de questions de recherche a été mis au point, ainsi que des schémas méthodologiques, puis des projets individuels et collectifs en série dans de nombreux pays et sur des situations culturelles très diverses. Il n'est pas excessif dès lors d'avancer que les DTS (Descriptive Translation Studies) n'auraient pas existé sans le programme des recherches polysystémiques, et que, plus globalement, les recherches sur la traduction n'auraient sans doute pas eu de statut universitaire sans le PS. L'essor du PS dans plusieurs disciplines voisines (les études cinématographiques, les recherches sur les médias, sur l'organisation sociale, etc.) a favorisé des combinaisons avec d'autres approches tout en rendant moins spécifique le profil de l'approche. On est en droit d'estimer que le PS s'est ainsi mis au service de la recherche au lieu de servir ses propres fins. En fait, tels furent exactement, semble-t-il, les objectifs officiels dès l'origine.

Tous droits réservés @ TTR: traduction, terminologie, rédaction — Les auteurs, Ce document est protégé par la loi sur le droit d’auteur. L’utilisation des 1995

services d'Érudit (y compris la reproduction) est assujettie à sa politique d'utilisation que vous pouvez consulter en ligne.

https://apropos.erudit.org/fr/usagers/politique-dutilisation/ 


\title{
Translation, Systems and Research: The Contribution of Polysystem Studies to Translation Studies
}

\author{
José Lambert
}

"My own work has naturally advanced in stages and has, deliberately, not offered a synthetic view." (I. Even-Zohar)

Since about 1975 many articles on translation have dealt with the so-called polysystemic approach, known also under several other labels and often identified as a group (from inside) or even a school (from outside). The very fluctuation in the names given to an approach or to scholars who are supposed to behave as a group/ school is, like most kinds of neologisms, interesting in itself but it generally implies simplifications, value judgments, and also polemics. Hence clarification and first-hand information are useful in themselves. But who can provide them without being personally involved? On the other hand it may be worthwhile to evaluate first of all the contribution of the Polysystem approach to Translation Studies. Given the fact that I have written many articles in favour of the PS approach, I am obviously part of a delicate if not utopian enterprise, being both evaluator and evaluated. It may, however, be an opportunity to demonstrate how this particular kind of systemic approach is perfectly aware of the fact that the scholar himself, while trying to describe and explain cultural phenomena in terms of values, does not function in an ideal world without norms. Anyway, 
dealing explicitly with PS after having kept silent ${ }^{1}$ on this matter for many years is more than just a challenge. Hence my attempt to proceed sine ira et studio.

\section{Back to the origins}

One of the first difficulties specific to the reception of the PS model is that although its aims are and have always been interdisciplinary, the history of its perception cannot be isolated from the history of more individual disciplines. PS is known mainly within Literary Studies and especially within Translation Studies, which may give the impression that its range and ambitions are limited to some particular disciplines and even more to one discipline, since specialists in translation are not necessarily specialists in literary research and vice versa. While reacting against such a reduced scope, I nevertheless feel entitled to deal here mainly (though not exclusively) with Translation Studies. One of the consequences will be that Gideon Toury's name will be used much more often than Itamar Even-Zohar's. Due to institutional as well as personal factors Toury has been involved in translation whereas his master has dealt more generally with semiotics and with PS. The personal history of scholars plays a role in the institutionalization of research, and vice versa: the father of the PS theory has been more influential in Literary Studies than in Translation Studies. One of the paradoxes is that Toury has never behaved like a propagandist of a given scholarly model and that he has rather avoided putting his own key concepts under any label that might have excluded him too radically from others. The personal history and career of many other disciples of the PS theory have influenced its contemporary status in a similar

1. Theo Hermans mentions that the advocates of the PS approach have more or less stopped mentioning this theoretical model (Hermans, 1994). In fact they may be convinced (as I am myself) that the best way of serving it is not necessarily to keep theorizing about it but rather to use it as a heuristic and methodological tool. It is also the best way to avoid polemical discussions. 
way. The consequence is again that PS to be much less interdisciplinary than it claims and deserves to be.

Like most historical phenomena "Polysystem" is a problem in itself and as a concept. Let us look at the name and the thing again. Many colleagues dealing with translation know it from Theo Hermans' Manipulation of Literature (Hermans, 1985) which was an attempt - a successful one by the way - to summarize some main trends in an approach which began at least ten years earlier. Theo Hermans himself was in a privileged position since he had attended one of the first key moments, the Leuven symposium "Literature and Translation" (1976), as an observer rather than as an active participant. The title "Manipulation" and the name "Manipulation group" are due to a concatenation of insiders' and outsiders' jokes rather than to any programmatic perspective, but it is used more or less commonly in Translation Studies, especially since Mary SnellHornby discussed it in her well-known Integrated Approach (Snell-Hornby, 1988). Confusion starts as soon as new trends are linked with individual scholars or collectives of scholars who are supposed to work in a given country. The label "Low Countries group" often refers to the PS approach, but it was coined and distributed mainly by James $\mathrm{S}$ Holmes, the American-Dutch poet-translator-scholar who, like several other colleagues in the Low Countries, rather disliked the PS hypothesis (Lambert, 1991). Whatever the contribution of the Low Countries - or rather: Flanders - may have been, PS theories have developed in Israel, first in Itamar Even-Zohar's work, then also and rather consistently in Gideon Toury's. They happen to have been revealed for the first time to a larger - though still very small - audience ${ }^{2}$ in Belgium.

2. The audience was small (not more than fifty) and so was the number of speakers (fourteen), but besides the speakers several participants who did not even deliver a paper have since established their reputation as knowledgeable scholars (Lieven D'hulst, Jürgen Fechner, Theo Hermans, Kitty van Leuven-Zwart, Maurice Pergnier, etc.). Some among the speakers, in particular Gideon Toury himself, started their international career in Translation Studies at the Leuven 1976 colloquium. 
Since then the promotion of the PS model has been rather heavily indebted to several individual scholars from the "Low Countries" who happened themselves to travel and to publish world-wide. Among many other semantic shifts, I should mention that the Leuven symposium was organized within one single department Literary Studies - and that many other representatives of the PS approach, while claiming more or less systematically that they wanted to revise borderlines, have been working mainly within similar departments, even more within Comparative Literature than within Literary Studies. The distribution and the promotion of the Leuven proceedings under a programmatic label, "Literature and Translation. New Perspectives in Literary Studies" (Holmes et al., 1978), has quite naturally followed international channels like the International Comparative Literature Association, where it traces important ideas until this very day ${ }^{3}$. Hence it has often been - quite wrongly - accepted that PS is a matter for literature and for literary translation only, and not at all a matter for translation in general, communication, semiotics, etc. But whatever the general ambitions of Even-Zohar, Toury and, later on, myself, André Lefevere or

3. The distribution of PS ideas within Comparative Literature started from 1979 on, during the Innsbruck Congress of the ICLA, and it has developed in a more or less programmatic way since 1982 (i.e. since the New York congress and the congress in Montreal) until today while remaining controversial and being systematically linked with literary research on translation. Even-Zohar (1990) and Tötösy (1992) offer a still limited survey of the PS research carried out within the ICLA frame since 1980. Most of the recent books on Comparative Literature devote explicit discussions to PS research (Guillén, 1985; Brunel \& Chevrel, 1989; Kushner, 1984). The PS approach is even considered as one of the most central innovations in the comparative study of literature in Dimic \& Garstin (1988), Moisan (1987 and 1990), Pageaux (1994) and especially in Lambert (1981) and Bassnett (1993). It is well-known that most theoreticians of Comparative Literature tackle only occasionally, if at all, the question of translation. On the other hand, several introductions to literary theory deal with PS theories more or less explicitly (Fokkema \& Ibsch, 1992) without taking into consideration the question of translation. 
others may have been, the real history and backgrounds of the "movement" have influenced its orientation and its image. "Nos actes nous suivent". Whereas translation used to be "the guilty conscience of Comparative Literature ${ }^{4}$," nowadays it has won a position within the International Comparative Literature Association which is inevitably linked with the PS model. Though still controversial from the point of view both of literary research and translation research, its basic features are at least known and hence partly established. One of the consequences is that even in Translation Studies many scholars still tend to reduce PS to its literary backgrounds. But those who started the "Literature and Translation" Symposium in 1976 today support translation research in an interdisciplinary way under the name "Descriptive Translation Studies" (which needs to be updated), they publish Target, they train researchers from many cultural and scholarly backgrounds at CETRA (the former CERA Chair) and they cooperate in world-wide handbooks for Translation Studies: the literary background is not forgotten but it gives a much too narrow idea of the PS model and its scope. One of the problems may be whether PS itself, hardly mentioned any more in the contemporary writings of its first promoters (Hermans, 1994), has also been forgotten.

\section{Goals of the discussion}

In the discussion and position paper that follows there will be no attempt at all to summarize again the basic principles and claims of the PS approach. Besides the programmatic key books (Even-Zohar, 1978; Even-Zohar, 1990; Toury, 1980) and a few programmatic articles (Even-Zohar, 1978; Toury, 1978; Lambert, 1981 and 1983b), several books and recent discussion papers (Hermans, 1985; Dimic \& Garstin, 1988; Tötösy, 1992; Iglesias Santos, 1994) have been published, in very different countries, much too often in isolation, sometimes while reducing PS to certain of its components

4. . Lefevere used the "guilty conscience" idea as a leitmotif in a brilliant paper given to the British Comparative Literature Society at Norwich in December 1975. 
and to certain cultural areas. From this angle PS has simply been treated as most new theoretical models.

My main intention is to reach those who want to re-examine the matter and those who want to learn more about it. I mainly want to demonstrate that PS has greatly contributed to the establishment of systematic research on translation, from within Translation Studies, but also while opening up the field from the point of view of other disciplines. Whether PS works itself as an established paradigm, as a school or as an operational theory will be left open. It is simply accepted that when research models have been operational in the past they may have a future. And this is the very reason why PS and its basic hypotheses deserve to be taken seriously by colleagues interested in research, whatever the name of the approach may be.

What PS exactly means may be reflected by the terminology used here. I shall distinguish between the first basic theory, called also the PS hypothesis (i.e. the idea that there is a systematic distinction/opposition between various theoretical/practical concepts of literature, translation, communication and that such oppositions tend to produce hierarchies). This theory has been used as a program for research, and not simply as a theory for its own sake (it is not a closed theory, which offers definitions once for all: all definitions have to be discussed and tested out), which implies the use of criteria/parameters for research (PS research; the PS model or frame). This is one of the key features of this theory: its aim is not to theorize but to provide models and methodology for research. Additional hypotheses and theories have been developed with reference to the same frame, which means that PS is more than one single theory or hypothesis. As every human enterprize the research has been carried out by many scholars in several centers and countries, sometimes with the aid of collective publications, which explains why certain colleagues take it for a school. However the idea of school obviously simplifies the relationship between the various publications, projects, centers and scholars, the more since the label PS is certainly used much less nowadays than between 1980 and 1990. Certain among these scholars (Even-Zohar, Toury, 
Lambert, Hermans, Lefevere) and centers (Tel-Aviv, Leuven) have been identified more directly with the PS theory than others, but the idea of monopolies and orthodoxy is a delicate matter in this context although the exact origin of most particular concepts and hypotheses can easily be traced. The relevance and the fruitfulness of the various hypotheses and methods developed along these lines is not at stake however. The quotation that opens my article is a program in itself: it indicates that Even-Zohar himself did not want to offer a finalized system of theories. It would be a strange paradox if those who have wanted to recognize him as a guide would have been more dogmatic.

Since articles are by definition supposed to be short, many key problems will be formulated and discussed in terms of (hypo)theses. Theses and hypotheses may favour discussion by making explicit what is often kept implicit.

It is a well-known fact, especially since Kuhn, that research is anything but a peaceful enterprise. Competition is everywhere, whether we like it or not, and so are attempts to change the scholarly world. For many of us the idea of competition is not strange at all, but this does not imply that we are always aware of it. The behaviour of scholars in general as well as their treatment of the PS model illustrate at least one of the key principles in socio-cultural matters that happens to be a key principle also in PS theory: the struggle for power. This very fact is interesting in itself because the (poly)systemic model has at least certain qualities lacking in most of the other contemporary theories developed in the Humanities since the 1960's: it seems to shake, to divide and also to influence a rather large number of scholars, it is in the worst of cases a polemical matter, and many among those involved in the often unwritten - polemics have a rather erratic behaviour since their praxis often contradicts their own theory. One of the strong arguments in favour of a model like the PS theory is that its relevance is rather confirmed than contradicted by the behaviour of scholars: the idea of competition is operational not simply in relation with texts or writers, but also in relation with scholars. PS theory teaches us a lot about a particular kind of social organization, i.e. 
scholarship. Whatever this may mean for its general relevance, it also teaches us how new hypotheses may help provide new insights in areas that are not officially at stake. Assuming that the PS model applies to the behaviour of scholars and to the scholarly world, we may conclude that its relevance cannot be reduced at all to literature nor translation and that it also explains something about (a very sophisticated) social behaviour. Is it correct, then, to oppose PS to "theories of action" like Habermas', Schmidt's, Bourdieu's etc. while assuming that PS applies to "communication" and not to "action" (cf. De Geest, 1993)?

Scholars' reactions to theories like the (poly)systems theory reveal a lot about their own positions and goals. It is clear that there have been many positive and negative reactions to the various systemic approaches and in particular to the PS approach. The lack of official (written) reactions on the side of many colleagues who have uttered their opinion in an unofficial (and oral) way cannot be without significance. Why do scholars react in an emotional rather than a scholarly way when new models develop in their field? The answer in systemic terms would be that new models are inevitably in competition with the previous ones and that they threaten established (power) positions. PS has no privilege either in its explanatory power or in its controversial position but it seems to be relevant in its hypotheses about human behaviour: scholars and scholarship are not innocent at all, they struggle for recognition and "distinction" (Bourdieu, 1979) and hence for prestige and power.

When looking for an explanation of this social behaviour among scholars, we do not necessarily need the Polysystem hypothesis, implying that other models are at least compatible with the PS theory. Another consequence of the relevance of the PS in matters of scholarly behaviour is that this particular theory may offer models and solutions for the observation of social behaviour, and not at all exclusively of literary or translational phenomena. What kind of a theory is it then if it has any relevance beyond the borderlines of disciplines such as Literary Studies and Translation Studies? 
Even-Zohar often claims that most of the PS hypothesis can be traced in the Russian formalists' work and particularly in the 1928 writings of Tynjanov. Besides indicating basic models, such references also belong to the rhetorics of theoretical thinking in research and in culture. Theoreticians as well as societies need to have their tradition and they may even need to create it. Russian formalism and even Eastern Europe (cf. Segall, 1982) are certainly an important background of PS. But the exact links with Russian Formalism are interesting for many other reasons. The ShlovskiTynjanov-Jakobson group was also something more than just a body of theories, it was above all a socio-cultural phenomenon, a group of artists-theoreticians-scholars that has never really pretended to offer a finalized body of theoretical models and still less a systematic enterprise of theory-based research. Secondly, the intellectual heritage of the Formalists (and Structuralists) remains unclear and controversial until this very day.

It may seem exaggerated to compare the PS movement with the Formalists' tradition. Yet both are the illustration of unsystematic collective activities where theory and practice do not always coincide. Above all, the use of history reveals in both cases how the past of theories belongs to the manipulation of history. Let us use one simple illustration: whatever Even-Zohar may have written, the formalists and Tynjanov in particular did not start their theories on the basis of translational experiences.

\section{The heterogeneity of cultures}

Rather than looking for historical relations let us focus now on the PS program and its implications, stressing more particularly the question of translation.

Unlike most other theories on language, literature and culture, including other systemic ones, Even-Zohar's discussions started on the basis of general considerations on the interaction between languages, literatures, societies and cultures while considering the heterogeneity - and the dynamics - of translated communication as a more or less particular kind of communication 
in and between societies and cultures. Many systemic models have been applied to literature and to society (from Bertalanffy to Luhmann), but hardly any of them have ever dealt with translation, and other recent attempts (Kittel, 1992) 5 have not proved very fruitful. Only PS theory uses translation as its starting point.

The idea of heterogeneity and hence of competition in literature, in language, in communication leads directly to the concept of norms. The only way to deal with heterogeneity is to look for regularities, hence for norms, maybe also for regularities within the norms observed. But norms themselves are not obvious

5. Kittel (1992) offers the Proceedings of a symposium in Göttingen on "histories" and "systems" (Göttingen, 1990) which cannot be isolated from the negative evaluation of PS in Frank (1989 and 1990). See De Geest (1993, pp. 26-47). In fact the Göttingen symposium put side-by-side several systemic approaches - some with hardly any tradition in research on translation and gave only a limited space to PS. Within Descriptive Translation Studies, the complex relationships between the important SFB "Die literarische Übersetzung" from Göttingen and the PS model could be used as an interesting test (for the impressive bibliography of the Göttingen SFB, I refer to the most central channel, the "Göttinger Beiträge zur internationalen Übersetzungsforschung": Frank et al. 1987- ). Armin P. Frank has often heavily reacted against PS and he has opposed his transfer oriented approach (defined in mainly negative terms, even in Frank, 1989) to Toury's target-oriented one, while being supported by several among his colleagues from the SFB, whereas other ones have adopted more flexible positions and discussed at length some particular points (Döring, 1989; Poltermann, 1992; Lönker, 1990). On the other hand some of the PS concepts and distinctions (such as source vs. target oriented) are commonly used in the same publications of the SFB. The typical Even-Zohar questions on the position that translated literature may occupy in a given culture have hardly left any discussion or influence. Which simply confirms that PS has been a real neighbour of the SFB and that it has been treated in an eclectic way. 
phenomena. How could we observe them without parameters, hence without hypotheses?

The use of hypotheses rather than more "traditional," i.e. more closed, theories, distinguishes the PS model from many but not from all other approaches to cultural phenomena. It implies the need for research: hypotheses have no relevance on their own, they may prove efficient or totally irrelevant. Only systematic and organized research can provide more established and more panoramic (still hypothetical) theories. The very idea of research introduces a new status for theories in the Humanities at a moment when static (i.e. closed) and eclectic or partial theories are rather popular. The ambition of PS was not at all to offer an attractive theoretical model for its own sake but to provide scholarship with concepts and tools that would allow a better and more systematic analysis of translational, literary or cultural phenomena.

Given its official openness and its use of hypotheses rather than of theses, PS theory can be only one among the (many) theories in disciplines dealing with literature, translation and/or communication. Notwithstanding its very general principles it cannot lay claim to any universalistic relevance nor monopoly.

One of the difficulties was, is and will remain what the exact status and aims of such a theory are: to account for translation and/or communication, language, sign systems (semiotics), literature? Given its backgrounds it cannot be disconnected from semiotics, literature, translation, but from the moment its hypotheses have a certain relevance in - say - social behaviour, media communication or politics the poly-valent status and ambitions of PS theory come to the fore.

It has been shown that PS theory is linked with a certain cultural (East-European) background (Segall, 1982). Literature, linguistics, translation are other aspects of such a background; it is not at all clear to what extent the systemic rules apply also to oral communication from the Middle Ages or from modern times. Such background problems seem to reduce the scope of any kind of 
theory, but the difference may be the way PS theory takes into consideration that theory is never and can never be developed out-of-space-and-time: when approaching any kind of object scholars are expected to bear in mind that their categories are themselves part of history whose relevance needs to be tested in empirical terms. Theoretical thinking itself will always have difficulties in escaping universalistic and thus static ambitions. Hence PS scholars will probably often overlook how limited and research-bound their models remain. This leads to some not unimportant quarrels about the exact status of systems (cf. Döring, 1989): are they mere hypotheses in themselves or would they exist as such in their Da-sein? How systematic and how coherent are systems in their dynamics and hence in their heterogeneity? If the general idea of norms and thus of hierarchy seems to be confirmed in many cultural situations - including translations - , it is not clear whether all cultural phenomena in any cultural situation are clearly submitted to hierarchies. The extent to which such relationships between, say, writers, translators and their audiences are also submitted to regularities between norms and hence to models (or schemes) is another matter for discussion.

The basic idea that literature (and/or communication and/or any kind of action) is not a matter of substance, but rather a matter of relations and that the aim of research is to study the principles underlying such relationships has indeed been formulated by Tynjanov, a long time ago, but also in Pierre Bourdieu's works since the seventies (cf. Bourdieu, 1994). PS theory does not have the monopoly on such a relational ("functional") approach to cultural phenomena but probably no theoretical approach - besides Bourdieu's - has made this more explicit. The exact relationship between various more or less explicitly systemic approaches like Siegfried J. Schmidt's and others (for a bibliographical survey see Tötösy, 1992) has hardly ever been discussed among the promoters of the various systems theories: the key theoreticians avoid rather than approach each other, which may in itself be an interesting confirmation of the competition/distinction principle. 
On the other hand, the systems concept is not the only way to deal with relations. Many more traditional approaches to language or to literature - such as sociolinguistics - are accustomed to the idea of relationships and conflicts. Hence many kinds of research appear to be compatible with PS/systemic approaches as long as their focus is on relations rather than on substances. This is why many disciples of the PS model hardly care (any more) about the (often too fetishistic but sometimes also too artificial) use of the word "system." The advantage of the PS frame seems to be that it provides scholars with a few explicit schemes and methods. The question remains: how limited or unlimited the resources are of a theoretical model that is flexible while being abstract and functional?

The evaluation of the PS model and its contribution to research in (at least) two disciplines is made difficult by the complex dissemination of texts and ideas in many isolated channels and in many different countries. While several theoreticians have adapted or innovated the model in several countries, often without any mention of their backgrounds, hardly anybody (not even Even-Zohar, 1990 or Tötösy, 1992) has a world-wide panoramic view on PS research.

Although many research programs have been worked out in recent years in order to account for the heterogeneity and the mobility of cultures, from deconstruction to pragmatics, it appears that none among them focusses more explicitly on the use of verbal communication as an aspect of language systems, literary systems and communication in general. The interaction between these different programs is a basic need for research as such. The only one however that integrates the matter of translation into the question of culture is the PS model.

\section{The heart of the matter: PS research rather than theory}

According to Even-Zohar, one of the first criteria for a discussion of the relevance of theoretical hypotheses is to establish whether they solve more problems in a satisfactory (systematic) way than other hypotheses (Even-Zohar, 1978). This is a very pragmatic point 
of view. Without further basic questions we might accept that the PS approach has had a positive impact on research from the moment it proved itself efficient. Given the fact that the focus was cultural phenomena like literature, translation, communication, it would be sufficient to indicate where successful research has developed on the basis of PS.

Only a few aspects of the recent history of Translation Studies can be traced here and it is impossible to discuss any of them at length. It will lead us into the history and historiography of the discipline (it could and should lead into other disciplines), where some developments described might be linked also with other models. Historians are aware that history cannot be accounted for in terms of monogenesis. It would be contradictory and counterproductive to provide polysystemic explanations while reducing the dynamics of research to one single paradigm. In certain particular matters, however, the dominant impact of PS in the renewal of our field remains quite obvious.

\section{Conceptualization}

Immediately after the Leuven symposium the distribution of the new PS theory linked rather than separated literature and translation. In the various international channels where PS penetrated and survived (often under other names), translation and literature have quite often been separated, which explains why many groups referring to the same basic texts ignore each other more or less systematically. This is in itself a sufficient way of justifying my discussion hic et nunc.

The concept of "Translation Studies" was promoted first by James S Holmes, then gradually accepted by many colleagues. It is true that the term "Traductology" (or "translatology"), notwithstanding its French backgrounds, is also quite common. One of the arguments against "traductologie"/"traductology"/ "translatology" is that it widens and simplifies the field since no distinction is made here between the research perspective and the practice and/or didactics-oriented perspective. The German "Übersetzungswissenschaft" and "Translationswissenschaft" do not make such a 
distinction very explicit either, but the idea of "Wissenschaft" is so heavy in this case that it refers more explicitly to research than does "traductologie". In fact the very distinction between the research-oriented approach and the practice/didactic- oriented approach is heavily indebted to Gideon Toury's norms concept and to his arguments in favour of a so-called descriptive approach. Whatever may have been written before 1976, the very idea that translation cannot really be defined without research and without a largely cultural and historical research program is due to Gideon Toury, who borrowed most of his key concepts (norms, models, systems, theory vs. descriptive research, etc.) from Even-Zohar. Distinguishing between many possible perspectives (the translator's, the reader's, the scholar's, the critic's) and locating them all in history, Toury and Even-Zohar have corrected the unilateral view on translation and go far beyond the translator's inevitably prescriptive point of view. This is a clear illustration of their struggle against a reductionist view on communication in general (where the focus is quite unilaterally on those who produce communication). Redefining the components of any translational activity and discovering a large network of parameters that may influence the translation and the communication process can be considered as the first research program for Translation Studies, and hence as the most explicit program of the discipline. Other approaches could have opened similar paths, but in the mid-seventies there were hardly any other research-oriented approaches. Nowadays "Descriptive Translation Studies" sounds redundant, but this was not at all the case in 1976, and "Translation Studies" has become quite common even in publications on Translation Training. Such a change indicates in itself how scholars dealing with translation have changed their position.

The opposition between "descriptive" and "prescriptive" perspectives is also rather common in contemporary translation theory, although it is not necessarily connected with the program of Descriptive Translation Studies (Bell, 1991; Gutt, 1991; Hewson \& Martin, 1991). Since the beginning of the 1980's the very influential Finnish-German "Skopos Theory" has also argued in favour of a more functional view on translation and interpreting. Justa 
Holz-Mänttäri and Hans Vermeer insisted very heavily on the "Skopos" (the function \& goal) of all translations, and their strong impact on the German tradition has proved to be parallel to Toury's target-oriented approach. However, their main goal was not to develop research but rather to develop translation and to improve its quality with the aid of didactics. Their theoretical background may look very different (it is indebted to Habermas and other German philosophers), but the important book by Katharina Reiss and Hans Vermeer (Reiss \& Vermeer, 1984) discusses at length the new concept of "norms" as used in Toury (1980). In fact many theoreticians have used the norms concept after and via Reiss \& Vermeer (1984), but without referring to Toury or to any PS frame.

I assume that the most crucial innovative impact in a discipline occurs in just such cases: when new concepts are used in a new frame and especially when such a usage has lost its own memory, i.e. when the new concepts look like the only possible ones, or appear to be "universals."

The impact of these new concepts cannot be reduced to the question of norms. It is the whole frame of oppositions and distinctions used nowadays by scholars dealing with translation that is more or less indebted to Toury's conceptualization and hence at least indirectly to the PS program, either in an explicit or in an implicit way. It is not the least interesting paradox that the impact of this conceptualization is particularly obvious when scholars and groups argue against it. The distinction between source-oriented and target-oriented translation strategies has been borrowed - often unknowingly and without any reference - from Toury and other PS-based scholars by many colleagues who have argued against PS; such a distinction was not perceived first within the PS model but it has been conceptualized there as part of an entirely new program. Other such distinctions and categories have been borrowed from the PS research program, often indirectly, sometimes directly and often without any explicit reference, which, again, may betray how basically the conceptualization of translation has changed since the seventies. 


\section{What has changed exactly?}

It is quite normal that scholars involved in discussions and in the flow of life do not perceive too well how their behaviour and their concepts keep changing. Like other human beings, scholars may have excellent reasons for denying change or for denying influences by particular people or events. According to Bourdieu a new anthropology is needed, also for the study of scholarly behaviour: sociologists, anthropologists and hence the Humanities in general tend to distinguish too simply between what is individual and what is collective, conscious or unconscious (Bourdieu, 1994). With the aid of particular methods, it is not always too difficult to establish when and where exactly new views have developed and how they may have conquered new individuals and groups. In the case of scholarly discourse on translation a few sudden shifts can be located and clearly linked with the use of the PS approach. Many first occurred during the 1976 symposium in Leuven, where suddenly the following questions were reformulated by several participants (as can be shown from their subsequent publications):

-What do we mean by translation?

- How can we plan research when we assume that there is no satisfactory theoretical model for the study of translation?

- What is the aim/the use of a theory?

-What is required for a theory to meet scholarly requirements?

-What is the relationship/distinction between theory and research? Why is (historical) research needed?

- How can we distinguish between normative and scholarly theories?

- What exactly is to be studied when we want to do research on translation?

- How can we account for translational phenomena in terms of norms?

- How do we relate the translators' and the critics' statements to translations?

- To what extent do societies and cultures play a role in individual translation processes?

- How can we relate the position of translations/translators to the translation method? 
- How can we account for incoherence and conflicts in translation processes?

- How do source and target cultures play a role in the selection, the production and the use of translations?

- How can we prepare historical research on translation?

- Why do we care more about the position of translations and translators than about "quality" as such?

- How can we deal with "quality" (norms) in translation while avoiding using our own norms as a basis for evaluation?

A much longer list of such questions could easily be established with the aid of publications issued soon after 1976 by the people who took part in the symposium: I refer in particular to James S Holmes, Susan Bassnett, Hendrik Van Gorp, André Lefevere, Raymond van den Broeck and myself, who delivered a paper, and to young observers like Theo Hermans and Lieven D'hulst. Some among these participants revised some of their concepts during the symposium itself (e.g. van den Broeck, who starts distinguishing between "prescriptive" and "descriptive" and who plans descriptive research), others, like Holmes himself, were hardly influenced and Bassnett, Lefevere, van den Broeck adopted some of the PS positions while refusing other ones. Similar observations might be made about (e.g. Canadian or South African) scholars who have assimilated the PS approach from a distance: their information channels and their research options are very differentiated. As can be seen especially in Snell-Hornby (1988 and 1995), it is mainly Hermans (1985), rather than Toury (1980) or Holmes $(1976)^{6}$, which is used for information on the "Manipulation group." But the PS disciples from Tel Aviv (in particular Zohar Shavit, Shelly Yahalom, Rakefet Sheffy) go back to the first-hand Israeli generation and combine them with European models (such as Bourdieu, in Sheffy's case) without using the Low

6. Many publications by members of the so-called "Manipulation group" are indeed hard to find, Holmes (1978) included, as mentioned in Snell-Hornby (1988): lack of power and lack of infrastructure are common features of new approaches. 
Countries' PS contributions at all. As a whole, the list of names and centers, the channels used, the questions asked indicate that, if there is a sociological phenomenon like a PS movement at all, it is anything but a school. There are more common grounds than common aims.

Many scholars, supervisors and groups of scholars have borrowed their research program very explicitly from the new theoretical discussions issued by the PS disciples. They have done so in many countries and in many departments, often with explicit reference to Even-Zohar, Toury, myself, Lefevere and others, but also quite often without using any explicit reference at all or while referring to occasional promoters of the PS approach. It can be assumed again that many occasional contributions to PS research, though often somewhat primitive and disappointing, are the best illustration of the innovative force of the new theoretical model (Cheung, forthcoming applies DTS to didactics). Even the explicitly negative discussions have contributed to the development of research and often also to a further sophistication in conceptualization. Among the most efficient disseminators of the new conceptual frame are the many colloquia on translation in various countries. Scholars are (also) social beings: though written evidence is almost totally lacking, many individual and collective research initiatives in the field of Translation Studies have their direct origin in colloquia around the world. The only way to catch this kind of evidence in the development of a new model could be a diachronic and synchronic analysis of the conceptual positions in the keynote papers before and after such colloquia.

\section{Institutionalization?}

The theme of the lack of research on translation has become a kind of leitmotif in certain areas of Literary Studies, but hardly at all in Linguistics, where it might be much more needed. The feeling that research was needed had no reason to develop within the institutes for the training of translators and interpreters. It is within the academic research world that the need for research and for institutionalized research programs had to be expressed first. 
Institutes for translator training have been kept out of the university in most countries - they have been created mainly in order to provide societies with translation services and were supposed to offer professional competence rather than to question the commissioner's commands. The education of translators and interpreters has been kept away from universities (and research centres) up to the present day and hence it is not yet accepted by societies as a matter for research?

The beginning of the conceptualization of research on translation started before 1975 and a certain time before any PS ideas were published internationally, among others in the articles by James S Holmes (later collected in Holmes, 1988). But in the case of PS research it was from within a university and from within university networks that the matter of translation gained recognition and that it was treated as a matter for research, also being provided with technical and methodological tools and, little by little, channels for communication. It is more than a coincidence that Transst, James S Holmes' newsletter, was created after the Leuven symposium and was taken up again by Toury more than ten years later: nowadays it is known world-wide. The institutionalization of channels promoting research on translation has taken several years and nowadays it is no longer very clear where exactly it started, but insiders can locate a few decisive moments. It is hard to imagine

7. I am well aware that this statement - often formulated elsewhere in State of the Art articles - looks much too general. First of all certain countries have integrated the training institutes into their universities (Canada has given an academic frame to translation training, Spain did so quite recently, some German centers are part of the university, the University of Amsterdam has just sacrificed the most important Dutch center; Italy has created at least 13 new centers, partly outside of the universities). The non-academic position of these institutes is confirmed by the fact that in many countries (Belgium included) the training institutes have no official access to the national research funds and their staff is often not supposed - so far - to have a Ph.D. degree or report on their research activities. 
how the establishment of the first society for research on translation (EST., i.e. the European Society for Translation Studies) would have taken off without the sudden connection between the institutes for translation training and the universities, represented mainly by small groups. Similar connections have probably been as decisive, a.o. the creation of the research group in Göttingen, probably the first real research group in Translation Studies outside of the machine translation projects. Neither in the establishment of the Göttingen SFB nor of EST the PS theory was mentioned, but the impact of Descriptive Translation Studies is obvious in the formulation of research goals by these new institutions. The idea of collective research based on explicit theoretical models and systematic corpora has in itself nothing specific to PS but it has been heavily promoted by those who initiated the idea of research on translation. This implies that neither the PS model nor any other model can claim to have changed the whole world of Translation Studies on its own but that their combination and interaction have provided a basis for a more institutionalized research situation. This aspect of history and of the history of research in general cannot be undone any more, although many universities and countries continue to regard translation and interpreting as a mere service and as a technical matter: it is their view that in societies with competent translators no research is needed...

\section{World-wide}

It has been said (a.o. Frank, 1989; Frank, 1990) that the more or less universalistic claims of PS cannot be taken seriously given the fact that only very limited cultural situations (French and Israeli ones) have been explored so far. It is true that the descriptive research started after 1975 is still limited. It is first of all hardly known and certainly not well promoted. But promotion is a matter of power. In fact many projects had dealt with various West-European, African and even Asian situations before 1990. It is due to a lack of systematic information and interaction that hardly anybody knows where the model has been tested out and used so far, but it seems that hardly any continents have escaped. It might be assumed that the only fair way of refuting or supporting new 
models is to test them out. It is a much more delicate matter to evaluate the exact relevance of the historical descriptive work carried out under the PS label and to establish to what extent it confirms, corrects or contradicts some of the basic ideas. Disseminating PS research may prove more or less successful but not necessarily revolutionary nor efficient, yet no scholars would refer to it if they were not convinced that it is preferable to other approaches. Research in the Humanities remains very amateurish to the extent that the frame for world-wide and permanent interaction on the basis of explicit questions and methods is hard to find ${ }^{8}$ (bibliography, journals, etc.). In recent years, however, more such opportunities have been developed than could ever have been expected, due to the support of some international societies and some new channels ${ }^{9}$.

One of the most interesting confirmations of certain PS hypotheses is provided nearly every time that scholars unaware of such hypotheses discover rules of translational behaviour. PS hypotheses cannot be confirmed unknowingly, but they may gain evidence when a better interaction with other approaches is favoured by the opportunities of open research. Other models might benefit

8. Although there are many excellent international bibliographies, a.o. in Linguistics, Pragmatics, many disciplines (like Literary Studies and in particular Literary Theory) lack basic tools, and the interaction between disciplines is hardly integrated into the best bibliographies (the CD-i bibliography of MLA will promote interdisciplinary approaches). But how can one establish with the aid of repertoires how intercultural our theoretical publications are in say sociology and what kind of theoretical models they use? Let us hope that the electronic era will promote better systems for detection and classification.

9. Besides international societies like ICLA or E.S.T., the activities of research groups, magazines and even centers for research training like CETRA (the previous CERA Chair) have had an obvious impact on the development of projects, Ph.D. research and a more organized approach to translation in general. 
if frames for systematic interaction would be available. The idea that particular projects ought to be put in touch with more general frames is not uncommon in other research traditions. The very search for efficient hypotheses within young disciplines is obviously not well developped. Such cases offer evidence that the use of more explicit methods and hypotheses would favour more efficient research plans and a more explicit discussion of possibly general (universal?) principles. In a similar way disciples of the PS model often enjoy how their colleagues, sometimes even while arguing against functional principles, stress unwillingly some of the leading principles developed by Even-Zohar, Toury or others (e.g. the role of prestige, power, politics in the traditions of translation; the importance through the ages of the "belles infidèles" principle as an aspect of the source/target conflict; fluctuations in the position of translation and their impact on translation strategies). But a few spectacular illustrations of PS research have been provided in cultural frames that were not envisaged from the beginning. Particular areas in the history of South East Asian, Latin American and African societies have been investigated with the aid of PS-oriented questionnaires (a.o. Lambert, 1985c; Hyun \& Lambert, 1994). Although in many circumstances new and unexpected problems arise, some of the most basic hypotheses prove relevant in quite particular cultural moments. On the basis of what has been demonstrated about the development of writing, scripture, alphabet and religious or legal traditions in Korea through the ages, it is obvious that even very traditional (closed) societies borrow some of their most central and canonized texts from other languages while coining their own tradition with the aid of translations and while at the same time setting different translational models against each other $^{10}$. It also seems that the treatment of neologisms and foreign

10. Theresa M. Hyun organized a conference at the University of York, Canada, in June 1994 where scholars from many disciplines examined the contribution of translation to the development of writing and language in Korea. No explicit reference was made of the PS model but the most obvious results of the discussions appear to be at least compatible with many key arguments in the PS model. 
names in the Korean, Chinese and Japanese languages is in itself an illustration of the well-known source/target conflicts ${ }^{11}$. A wonderful exploration of the history of missionary activities in Korea even leads to the observation that Canadian missionaries from the end of the 19th century supported their translation enterprise with a target-oriented translation campaign very similar to Eugene Nida's! Larger and collective investigation might help Translation Studies to discover more general principles underlying translational activities through the ages (a.o. the treatment of constitutions and all religious texts, those key texts of civilisation that have generally been imported and translated and that are finally considered as the heart of societies, though in fact of foreign origin ${ }^{12}$ ).

Even our modern age does not escape the discussion of general cultural rules and their fluctuation in translation. Since we have had mass media and world-wide communication channels it has become possible to observe international strategies as well as their changes. It seems that the treatment of foreign names (in translation and elsewhere) in various cultures might easily be approached with the principles provided by the PS model: target-oriented vs. sourceoriented strategies seem to be influenced by the openness/closedness of the receiving culture and by the prestige of the imported data. It is at least a sufficiently strong argument that so far very little seems

11. This is my own comment on work carried out by Richard Trappl (University of Vienna) on language policies in contemporary China (forthcoming in the Proceedings of the FILLM congress, Brasilia, 1993, ed. J. Lambert).

12. I refer to the Ph.D. research project of Jean-Baptiste Bigiriwana (Université Catholique de Louvain) on the Constitution in Burundi. The development of constitutions and religious canons is an aspect of the canonisation and colonization problem which has been approached from many angles in contemporary scholarship and where PS research offers at least some new contributions (Hyun \& Lambert, 1994; Lambert, forthcoming in Poltermann, 1995). 
to contradict the PS hypotheses on this matter. Why then not use them as a start for further discussion, maybe also for refinement?

It is again on the basis of the PS model that research has begun on film adaptation and also, more systematically, on media translation. From the moment communication transcends individual languages and nations we have the opportunity to re-examine how specific the relationships are between nations, societies, literatures, etc. (Lambert, 1989a). Moreover, the use of the new media technology places us in new cultural situations which allow us to redefine the relevance - if any - of particular hypotheses. It is in this context that one of the most explicit PS hypotheses about the source/target relationships may need to be reformulated : it seems indeed that although in most cultural situations translations fulfil a need from the target group's point of view, most contemporary international communications are needed from the moment such a need is created by a given source group (Lambert, 1989b). Contemporary societies redefine the whole game while disconnecting space, time, language, nation, etc., to an ever greater extent: source and target positions remain relevant but within new cultural, political, linguistic and economic frames. Within Translation Studies neither the question of mass communication nor that of media translation has been simply discovered by PS, but the general research program as worked out nowadays may has already been enriched by questions borrowed from PS.

In the course of our work with several colleagues to formulate general question schemes for an encyclopedia of Translation Studies (Frank et al., 1994), we have been well aware that one of the most basic questions ("What exactly does translation mean in a given society?") has often been asked in the past by scholars and intellectuals from many different cultures and disciplines. However, the tools available now for the organization of such questions and research programs have been formulated only quite recently. In their conceptualization, PS theory has obviously been a substantial player, maybe simply because it has offered the first explicit research program. Twenty years ago scholars would have reduced such questions to the problem of quality and hardly 
tackled the problem of functions. It is due to such assumptions that translation was considered to be a matter for translation scholars only - if at all - and not for the Humanities in general. The idea that translation is a matter for scholarly disciplines like sociology, linguistics, media studies, bible studies, colonial history, etc., is heavily indebted to the new questions raised since the seventies under the influence of the PS approach. There is no doubt that a "cultural turn" - as the Anglo-Saxon world likes to put it - has taken place, but its origin goes back to the many articles written in the mid-seventies about the way societies construct their translational concept along their value scales and on the basis of prestige and power.

\section{Beyond Translation: Neighbouring Disciplines}

From the moment the concept of norms is taken seriously, it is hard to conceive Translation Studies in static terms, i.e. independently of other disciplines. This is indeed one of the implications of Toury's thinking on the central role of norms. Before these considerations were known the so-called literary approach and the so-called linguistic approach to translation were clearly separated if not incompatible. Since then, many conferences on translation have devoted energetic debates to the redefinition of the borderlines between linguistics and literary studies as far as translation is concerned. It was some time before the redefinition of borderlines and competences was taken seriously but nowadays it is not an issue at all except among those who have failed to keep up with the evolution. Relating such a shift only to the discovery of PS and/or to Toury's influence would be foolish except to the extent that without them the norms concept would not have been adopted so suddenly.

It is a strange path that leads from psychology - where important aspects of systems theory have developed since the fifties - into sign systems, linguistics, literary studies, translation studies and back to psychology. Disciplines that have their own history are now establishing new contacts and exchanging their experiences in an interdisciplinary way. Strangely enough colleagues from (social) 
psychology dealing with the language problem become extremely critical from the moment other disciplines apply "functional" (i.e. "systemic") approaches (Janssens \& Steyaert, forthcoming). In their mind, functional approaches are prototypical of mechanical and instrumental views. They distinguish between "cultural" and "instrumental" (mechanical) views on language while examining the extent to which language is a distinctive feature of societies. Sociologists have similar objections against functional(ist) views ${ }^{13}$, with systemic views supposed to be one of the extreme options of functionalism. It is on the basis of such considerations that they argue against any a priori definition of societies and their links with religion, language, politics, race, etc. But then also they look for the values (norms) and models that underlie societies with the aid of strong empirical methods. Only the consensus on norms (values) offers a sufficient basis for "societies" of any kind, which leads us back to the PS hypotheses on literature, communication, language, culture, etc. Such a reconstruction of societal principles beyond nation/language traditions offers a new tabula rasa where the principle of communities could be rediscussed (see the idea of "world maps" in Lambert, 1989a) ${ }^{14}$.

13. A simple look at the item "Fonction et fonctionnalisme" in the Encyclopaedia universalis (1985) (VII, pp. 1086-1090) gives a panoramic view on the discussion.

14. Besides the many handbooks on Linguistics, see Joshua Fishman's work, his International Journal for the Sociology of Language (1974- ), Jan Nuyt's and Jef Verschueren's Comprehensive Bibliography of Pragmatics (Benjamins, 1987, 4 vol.), etc.: a simple look at subject indexes confirms that the question of translation is not considered to be a central issue. One may add that in the very succesful area of intercultural communication basic channels such as Geert Hofstede's books and the International and Intercultural Communication Annual (Newbury Park, London and New Delhi, Saga) not only the question of translation but even the question of language appears to be peripheral. 
Language is just one of the values underlying societies and it is assumed that societies do not have languages, they produce and manipulate and organize them. It is one of the fascinating experiences offered by the PS approach to translation that it leads into exactly the same positions as business communication and business management of the globalization era: in this world view languages do not coincide with standard languages, nations are no clear borderlines for languages and not even for societies; national societies are just one of the institutionalized societies, and when they are changing or reshuffled languages often play more than an instrumental role, they may become a key factor (see a.o. Janssens \& Steyaert, forthcoming; Herrlitz et al., forthcoming). Whereas systems thinking of the traditional kind appears to be strictly deterministic and to exclude heterogeneity - this is at least one of the common objections, sometimes even against $\mathrm{N}$. Luhmann's and S. J. Schmidt's works -, PS research on language, translation and literature stresses the dynamics of norms and value scales while starting from the idea of heterogeneity (Lambert, 1989a). The cooperation between disciplines such as marketing research, business communication, management studies and social psychology on the one hand and translation studies on the other opens new perspectives (Janssens \& Steyaert, forthcoming; Herrlitz et al., forthcoming). Again, functional principles are not that new, not even in Translation Studies, but they were not formulated as a basic matter for translation before the mid-seventies.

Sociolinguistics has provided the PS theorists with some of their most basic ideas. It is rather surprising after all that contemporary sociolinguistics, pragmatics (and the leading trends in research on intercultural communication) still keep translation out of their realm. One would assume that such an observation in itself is enough to establish that the questions asked by sociolinguistics, the sociology of language and also pragmatics are still very limited and artificial, and that they fail to tackle the internationalization process. An approach to the concept of language must be a narrow one if it excludes the question of translation. It is again on the basis of PS that a dialogue with sociology, with the sociology of language and with sociolinguistics has started. This happened first of all via the 
interaction between Pierre Bourdieu's work and PS, a.o. in Rakefet Sheffy's work (Sheffy, 1990), but also in Even-Zohar's and in my own recent articles ${ }^{15}$. Furthermore it is obvious that Anthony Pym's refreshing views on translation as an aspect of international societies find their best neighbours in Translation Studies among the PS disciples (see Pym, 1992a and 1992b).

Media studies and communication studies have also been using systemic models of different kinds, while exploring PS as a new ground for research on film adaptation, film translation and media translation in general (cf. Cattrysse, 1992) ${ }^{16}$. The strongest way to demonstrate how much Translation Studies needs to be interdisciplinary is indeed to use it as a task for research on the new media. This is simple in principle since specialists in (mass) communication for a long time have used the well-known schemes that linguists and literary scholars, and now also scholars in Translation Studies, apply to their object. However obvious the task of Translation Studies may be in matters of media and communication, the institutional traditions of universities and other centres do not make cooperation plans too simple. In countries like Belgium and Spain research and even teaching programs have been opened to media translation. It seems again that the basis for a programmatic treatment of language, translation and the media can again be borrowed partly from the polysystemic views on intersemiotic communication (see note 15 ).

15. Let me refer to some of my own articles in preparation: "Translation, Societies and Shifts of Values"; "Language and the Media: A Research Program"; "Translation and the (Non-) Canonization of Otherness"; "Implicit Discourse on Translation: A Key to the Encyclopedia of Culture"; "Verbal Communication Revisited: Didactic Tools and Empirical Research for the Treatment of Languages in the Media World"; "Literarische Mehrsprachigkeit: Grundregel oder Ausnahme?"

16. See also the works by Bordwell and his colleagues on the Hollywood traditions. 
It is of no use to mention every particular new use of PS models in the field of Translation Studies, not even in order to demonstrate how many different areas have been discovered and explored. It would be naive indeed to conclude from this proliferation of initiatives and from its diversity that PS can function as a magic tool. Just like other approaches it requires continuity and follow-up. Yet it has stimulated innovation. Hence one basic merit is clear: no other approach in Translation Studies - let us keep other disciplines for other occasions and debates - has generated more projects, questions and investigations during the last twenty years.

\section{Limits, Shortcomings, Debates}

Rather than discussing the basic relevance/irrelevance of the PS approach, $I$ have just indicated in what areas it has claimed to innovate research and in what areas it has indeed produced new investigations. It would be counterproductive to try to examine in merely theoretical terms how far PS theory is right or wrong. Those who want to clarify such matters without having tested them out have by definition missed one of the starting points of this particular research program.

But there are definitely some weaknesses and shortcomings in the research carried out so far under the PS label or on behalf of PS. Besides possible - or inevitable - shortcomings in the formulation of its goals, PS theory has to rely on systematic (historical-descriptive) research. More than any other model in this area it is useless without research. This implies the interaction between theory, methodology and the actual research, which in turn implies an infrastructure in terms of manpower, institutional infrastructure and budgets. The strength of such approaches is also their weakness. How could new models for research meet such requirements from the beginning? Interdisciplinary research has a tough time in our rather feudal-looking academy, where lobbies rather than scholarly arguments decide about disciplines. Moreover, collective research as such is hard to start up in the Humanities. Would this then mean that real research is not possible at all in the Humanities? Whatever the answer may be, PS research itself, like 
other functional research models, explains quite well why research as such is in trouble and why research focusing on norms and power without trying to support them will always be perceived as a threat. It is so much easier, after all, to use research as a way of celebrating heroes, stars and morality.

The goals of PS research are/can be made so general that one may wonder whether they can coincide with any particular discipline. They focus on the basic rules of communication and hence also of societies. To the extent that they deal with relationships rather than with substances (in harmony with Tynjanov but also with Bourdieu), they can hardly be alien to any kind of socio-cultural research or anthropology.

Rather than discussing these very basic and general questions I have tried to locate some more particular results. I have avoided discussing again particular arguments from the rather isolated debates, partly because they seem not to compromise the use and the possible efficiency of the approach as such. Whether the "system"/"mega- polysystem" has any status in itself or whether it is just a beautiful hypothesis stops being the (main) point from the moment it allows new kinds of relevant research. Whether it is an anti-humanistic view on literature and culture - as a few comparatists tend to say, revealing how they submit to values rather than investigate them - is not the point either: research itself is probably anti-humanistic in as much as its first aim is to promote knowledge rather than to improve mankind (which may be a consequence of knowledge). How could one avoid being deterministic - and anti-humanistic - while assuming that (a) may have a given impact on (b)? For many literary scholars the real enemy is simply research itself. The attempt to demonstrate (Frank, 1990; see the discussion in De Geest, 1993) that PS cannot work since it does not conform to a saussurean concept of system (or to a pseudo-saussurean one?) is not the point either since there are obviously many other non-saussurean concepts of system (Kittel, 1992). More local misunderstandings, e.g. about the opposition between source and target oriented translation strategies, or the necessity to study translations in relation to "the original," do not 
even need to be reexamined: it may be sufficient to re-read some of the key texts carefully. Many misunderstandings about the possible relevance of the PS model are indeed due to simple misreadings or to eclectic information, generally limited to particular theoretical discussions and excluding historical-descriptive work. It is true, however, that neither the theoretical nor the historical-descriptive work is accessible to everybody.

A few key issues (sometimes clichés) among the objections against the PS model deserve to be listed here:

- before dealing with systems one ought to know whether they are just heuristic tools or whether they have an ontological and hence an a priori status (Döring, 1989; Geldof, 1986);

- before assuming that systems exist and that systemic patterns can be observed we should assume that only certain particular, i.e. closed or static systems can be taken into consideration (Frank, 1990);

- decisions, behaviour and norms are idiosyncratic (and hence not systemic), which also means that translations and translators, especially in the case of translated literature, are mainly individual (Frank, 1990);

- translations and translators cannot be explained by target-oriented principles (the idea that translations and translators cannot be explained - only - by source-oriented principles is rarely used against Toury, although it would make nearly as much sense as the anti-target-thesis);

- translations and translators are not peripheral phenomena (see Berman, 1995);

- translations and translators are not central ("important") phenomena (see the traditions of Comparative Literature);

- "descriptive" research is impossible since it would demand (total) objectivity (this objection is often used by historians of national literatures, hardly ever in writing);

- Toury's target-oriented approach is compromised by the discovery that there are many (mainly) source-oriented translations; PS approach to translation excludes the observation of the relationships between translational phenomena and the source culture/text (Frank, 1990); 
- descriptive research does not make sense since it does not lead into evaluation or quality judgments (Berman, 1995; Snell-Hornby, 1995);

- PS approach to translation is too narrow because it excludes translational phenomena that are not labelled as such in a given culture (Cattrysse, 1992).

By listing here obvious misunderstandings and misreadings together with more serious difficulties - such as the last one - we intend to indicate among other things that objections are interesting in most cases, often just because they reveal basic aspects of common belief. The most interesting misunderstanding is probably the idea that theoretical models are compromised as soon as they have to be revised, or just tested out, and/or that they could be seriously examined in terms of good and bad.

Such misunderstandings have hardly any direct connection with the particular models at stake. Superficial concepts are not at all the monopoly of those who discuss PS, in negative or in positive terms. The too easy and naive use of the PS model has often rather compromised it, in particular when "system" is just another name for "country," "literature" or "language."

It would be a much stronger argument in favour of a systemic approach that our traditional approach to languages, literatures, countries and nations appears to be far too static in our media age. This is why the idea of a new "cartography" of cultures has been one of my own hobby horses in recent times, as a consequence of the evidence of the mobility of nations, languages and traditions in general (Lambert, 1989a). In fact neither Even-Zohar nor Siegfried J. Schmidt, nor Bourdieu or Fokkema \& Ibsch (1992) try to make explicit with what kind of concrete institutions their systems concept coincides. The exact relationship between systems and (political) institutions may become the heart of the matter in a contemporary world where the new societies (as in the case of multinationals and information societies) and new nation-states develop all the time: in case there are actually any 
systems on our planet, where exactly can we locate them? Where are their borderlines? Would such borderlines be space-bound at all?

Whatever the answers may be, whatever the compatibilities and incompatibilities may be between the various approaches that claim to tackle such problems, the most striking contribution of (poly)systemic thinking on translational phenomena is that it has generated a methodology, maybe various methodological models for research. Not on its own, but perhaps in a more pervasive way than any other well-identified model. The exact name and origin of such contributions to research are obviously less important than their role.

\section{Survival: 1975 - 1995, and beyond?}

Until 1980 the limited number of scholars who referred explicitly to the PS frame as a basis for their research organized three colloquia (Leuven, Tel-Aviv, Antwerp). From 1980 they did not feel any further need for "isolated" colloquia and they have rather used other channels (such as ICLA). Little by little they have kept from the PS approach a large number of questions, ideas, methods rather than the name. At the same time they have stopped behaving as a social group while combining their work with new partners along compatible principles. The paradox is that PS has probably been transformed into research under various labels and that it has probably lost its programmatic identity while just promoting research more than the institutionalization of particular research labels. It wants to be future-oriented, not unlike Descriptive Translation Studies: "descriptive research, and beyond" (Toury, 1995). Which probably indicates that PS does not exist on its own, certainly not as an organized frame, but that it has changed the scope of Translation Studies and that it has probably contributed to changes in other ones. Under what kind of a label it has chances to survive is probably not the point.

José Lambert: Departement literatuurwetenschap, Katholieke Universiteit Leuven, Blijde-Inkomststraat 21, B-3000 Leuven 


\section{References}

General Note: The list of basic texts on PS has been reduced to a minimum here since Even-Zohar (1990) and Tötösy (1992) have listed most of them. Under sections II and III a rather long but still very selective survey is given of discussions and descriptive work that have not been summarized before.

\section{Key Texts on PS in general:}

DIMIČ, Milan V. \& Marguerite K. GARSTIN (1988). The Polysystem Theory. A Brief Introduction, with Bibliography. Edmonton, University of Alberta (Papers on the Theory and History of Literature, 1).

EVEN-ZOHAR, Itamar (1978). Papers in Historical Poetics. Tel Tel-Aviv, The Porter Institute for Poetics and Semiotics (Papers on Poetics and Semiotics, 8).

(1979). "Polysystem Theory," Poetics Today, I, pp. 287-310.

(1990). "Polysystem Studies," Special issue of Poetics Today,

$\mathrm{XI}(1)$.

(1994). "La Función de la literatura en la creación de las naciones de Europa," in Dario Villanueva, ed. Avances en teoria de la literatura (Estética de la Recepción, Pragmática, Teoría Empírica y Teoria de los Polisistemas). Santiago de Compostela, Universidad de Santiago de Compostela, pp. 357-377.

LAMBERT, José (1983b). "Un Modèle descriptif pour l'étude de la littérature. La Littérature comme système complexe."(Kortrijk)Faculteit Letteren \& Wijsbegeerte, Universitaire Campus Kortrijk. Paper no. 29. Also in Contextos (León) V(9), 1987, pp. 47-67.

TOURY, Gideon (1980). In Search of A Theory of Translation. Tel Tel-Aviv, The Porter Institute for Poetics and Semiotics (Meaning and Art, 2). 
(1985). "A Rationale for Descriptive Translation Studies," in Hermans (1985), pp. 16-41.

(1986). " Translation. A Cultural-Semiotic Perspective," in Thomas A. Sebeok, ed. Encyclopedic Dictionary of Semiotics. BerlinNew-York-Amsterdam, Mouton de Gruyter, II, pp. 111-1124.

(1995). Descriptive Translation Studies, and Beyond. Amsterdam \& Philadelphia, Benjamins (Translation Library).

\section{Discussion}

DE GEEST, Dirk (1993). Literatuur als systeem. Bouwstenen voor een systemisch-functionalistische benadering van literaire verschijnselen. Proefschrift ingediend ter verkrijging van de graad van Geaggregeerde voor het Hoger Onderwijs. Leuven, Departement Literatuurwetenschap. [Dissertation.]

DÖRING, Sabine (1989). "Literatur als semiotisches System. Eine kritische Analyse von Itamar Even-Zohars 'Polysystem Theorie'," Frame, IV(1), pp. 23-39.

EVEN-ZOHAR, Itamar and Gideon TOURY, eds. (1981). Theory of Translation and Intercultural Relations. Tel-Aviv, The Porter Institute for Poetics and Semiotics, Tel Aviv University. [Poetics Today II(4).]

FRANK, Armin Paul (1989). "'Translation as System' and Übersetzungskultur, On Histories and Systems in the Study of Literary Translation," New Comparison, 8, pp. 85-98.

(1990). "Systems and Histories in the Study of Literary Translations: A Few Distinctions," in Roger Bauer \& Douwe W. Fokkema, eds. Proceedings of the XIIth Congress of the International Comparative Literature Association. Munich, 1988. Space and Boundaries. Plenary Sessions. Munich, Iudicium, I, pp. 41-63.

et al. (1994). "Übersetzung - Translation - Traduction: An International Encyclopedia of Translation Studies," Target, VI(1), pp. 67-80. 
GELDOF, Koenraad (1986). Problèmes épistémologiques et idéologiques dans la théorie du polysystème littéraire. Essai critique. Kortrijk, K.U.L.C.K. (Preprints, 43).

(1993). La Voix et l'événement. Pour une analyse du discours métalittéraire. Louvain \& Montréal, Presses universitaires de Louvain $\&$ Éditions Balzac (L'univers du discours).

HERMANS, Theo, ed. (1985). The Manipulation of Literature. Studies in Literary Translation. London, Croom Helm.

IGLESIAS SANTOS, Montserrat (1994). "El sistema literario: teoría empírica y teoría de los polisistemas," in Dario Villanueva, ed. Avances en teoría de la literatura (Estética de la Recepción, Pragmática, Teoria Empírica y Teoria de los Polisistemas). Santiago de Compostela, Universidad de Santiago de Compostela, pp. 309-356.

LAMBERT, José (1981). "Plaidoyer pour un programme des études comparatistes. Littérature comparée et théorie du polysystème," in $\mathrm{M}$. Brunon, ed. Actes du Congrès de la Société Française de Littérature Générale et Comparée, Montpellier, 1980. Montpellier.

(1989a). "À la Recherche de cartes mondiales des littératures," in János Riesz \& Alain Picard, eds. Semper aliquod novi. Littérature comparée et Littératures d'Afrique. Mélanges offerts à Albert Gérard. Tübingen, Narr, pp. 109-121. English: "In Quest of Literary World Maps" in Harald Kittel \& Armin Paul Frank, eds. Interculturality and the Historical Study of Literary Translations (Göttinger Beiträge zur internationalen Übersetzungsforschung, 4). Berlin, Schmidt, 1991, pp. 133-144. Spanish: "En busca de mapas mundiales de las literaturas," in Lisa Block de Behar, ed. Términos de comparación. Los Estudios literarios entre historias y teorias. Academia Nacional de Letras. Segundo Seminario Latinoamericano de Literatura Comparada, Montevideo, agosto de 1989. Montevideo, Academia Nacional de Letras, pp. 65-78.

(1991). "Shifts, Oppositions and Goals in Translation Studies: Towards A Genealogy of Concepts," in van Leuven-Zwart, Kitty \& Ton Naaijkens, eds. Translation Studies: The State of the Art. Proceedings 
of the First James S Holmes Symposium on Translation Studies. Amsterdam, Rodopi, pp. 25-37.

LEFEVERE, André (1990). "The Dynamics of the System: Convention and Innovation in Literary History," in Theo D'Haen, Rainer Grübel \& Helmut Lethen, eds. Convention and Innovation in Literature. Amsterdam \& Philadelphia, Benjamins, pp. 37-54.

(1991). "Translation and Comparative Literature: The Search for the Center," TTR IV(1), Special Issue on "Languages and Cultures in Translation Theories," ed. by the FIT Committee for the Theory of Translation, pp. 129-144.

(1992). Translating Literature: Practice and Theory in a Comparative Literature Framework. New York, MLA.

ed. (1982). "The Art and Science of Translation." Dispositio (Revista hispanica de semiótica literaria), VII(19/20/21).

PYM, Anthony (1992). "The Relations Between Translation and Material Text Transfer," Target IV(2), pp. 171-189.

SEGALL, Dmitri (1982). "Israeli Contributions to Literary Theory," in Elrud Ibsch, ed. Schwerpunkte der Literaturwissenschaft ausserhalb des deutschenSprachraums. Amsterdam, Rodopi (Amsterdamer Beiträge zur neuen Germanistik, 15), pp. 261-292.

TÖTÖSY de ZEPETNEK, Steven (1992). "Systemic Approaches to Literature - An Introduction with Selected Bibliographies," Canadian Review of Comparative Literature, XIX(1-2), March/June, pp. 21-93.

(1993). Bibliography of Works in the Systemic and Empirical Approach to Literature 1. IGEL, International Society for the Empirical Study of Literature.

III. Functional-Systemic approaches: theory, research, innovations

BASSNETT, Susan (1993). Comparative Literature. A Critical Introduction. Oxford \& Cambridge, Blackwell. 
BELL, Roger T. (1991). Translation and Translating. London, Longman.

BERMAN, Antoine (1995). Pour une critique des traductions: John Donne. Paris, Gallimard (Bibliothèque des Idées).

BORDWELL, David, Janet STAIGER and Kristin THOMPSON (1985). The Classical Hollywood Cinema: Film Style and Mode of Production to 1960. London, Routledge and Kegan Paul.

BORDWELL, David and Kristin THOMPSON (1993). Film Art: An Introduction. New York, McGraw-Hill.

BROECK, Raymond van den, \& André LEFEVERE (1984, 2nd ed.). Uitnodiging tot de vertaalwetenschap. Amsterdam, Coutinho.

BOURDIEU, Pierre (1979). La Distinction. Critique sociale du jugement. Paris, Minuit.

(1982). Ce que parler veut dire. L'Économie des échanges linguistiques. Paris, Fayard.

Seuil.

(1994). Raisons pratiques. Pour une théorie de l'action. Paris,

BRUNEL, Pierre \& Yves CHEVREL (1989). Précis de littérature comparée. Paris, PUF.

CATTRYSSE, Patrick (1992). Pour une théorie de l'adaptation filmique. Le film noir américain. Berne, Berlin, Francfort/Main, New York, Paris, Vienne, Lang. (Regards sur l'image, série II, Transformations.)

CHEUNG, Martha (forthcoming). "Descriptive Translation Studies and the Teaching of Literary Translation." Cay Dollerup, ed. Teaching Translation and Interpreting. New Horizons. Third 'Language International' Conference. Elsinore, 9-11 June 1995. 
DANAN, Martine (1991). "Dubbing as an Expression of Nationalism," Meta, XXXVI(4), pp. 606-614.

(forthcoming). From Nationalism to Globalization. France's Challenges to Hollywood's Hegemony. Ph.D. Michigan Technology University, 1994.

DELABASTITA, Dirk (1989). "Translation and Mass-Communication: Film and TV-translation as Evidence of Cultural Dynamics," Babel, XXXV(4), pp. 193-218.

(1990). "Translation and the Mass Media," in Susan Bassnett \& André Lefevere, eds. Translation, History and Culture. London, Pinter, pp. 97-109.

D'HULST, Lieven (1987). L'Évolution de la poésie en France (1780-1830). Introduction à une analyse des interférences systémiques. Leuven, Leuven University Press (Symbolae series D, 1).

D'HULST, Lieven, José LAMBERT \& Katrin VAN BRAGT (1980). "Littérature et traduction en France (1800-1850). État des travaux," in Zoran Konstantinovic, ed. Proceedings of the LXth International Congress of the International Comparative Literature Association, Innsbruck 1979. Innsbruck 1980, II, pp. 301-307.

FOKKEMA, Douwe F. \& Elrud IBSCH (1992). Literatuurwetenschap \& Cultuuroverdracht. Muiderberg, Coutinho.

FRANK, Armin Paul a.o. (1994). "Forum. Übersetzung - Translation Traduction. An International Encyclopedia of Translation Studies," Target VI(1), pp. 67-80.

GENTZLER, Edwin (1993). Contemporary Translation Theories. London \& New York, Routledge (Translation Studies).

GILLESPIE, Gerald (1992). "Rhinoceros, Unicom, or Chimera? - A Polysystemic View of Possible Kinds of Comparative Literature in the New Century," Journal of Intercultural Studies, 19, pp. 14-21. 
GORIS, Olivier (1993). "The Question of French Dubbing: Towards A Frame for Systematic Investigation," Target V(2), pp. 169-190.

GUILLÉN, Claudio (1985). Entre lo Uno y lo Diverso. Introducción a la literatura comparada. Barcelona, Editorial crítica.

GUTT, Ernst-August (1991). Translation and Relevance. Cognition and Context. Oxford, Blackwell.

HERMANS, Johan \& Peter SIMOENS (1993). "La Traduction, un aspect du marketing. L'Internationalisation n'a pas (vraiment) eu lieu," Marketingjaarboek. Annuaire marketing 1993. Cyriel Van Tilborgh \& Rik Duyck. Eindredaktie, Luk Lammens. Zellik, Roularta Books \& Stichting Marketing, pp. 27-33.

HERMANS, Theo (1991). "Translational Norms and Correct Translations," in Kitty M. van Leuven \& Ton Naaijkens, eds. Translation Studies: The State of the Art. Proceedings of the First International James $\mathrm{S}$ Holmes Symposium on Translation Studies. Amsterdam/Atlanta, Rodopi (Approaches to Translation Studies, 9), pp. 155-169.

(1994). "Vertaalwetenschapin de Lage Landen," Nederlandica Extra Muros, XXXII(3), October, pp. 1-13.

HERRLITZ et al. (forthcoming). Verbal Communication in Professional Settings. Utrecht, June 29th-July 1st 1995.

HEWSON, Lance \& Jacky MARTIN (1991). Redefining Translation. The Variational Approach. London \& New York, Routledge.

HOLMES, James S (1972 [1975]). The Name and Nature of Translation Studies. Amsterdam, Translation Studies Section, Department of General Literary Studies.

HOLMES, James S, José LAMBERT \& Raymond VAN DEN BROECK, eds. (1978). Literature and Translation. New Perspectives in Literary Studies. Leuven, Acco. 
(1988). Translated! Papers on Literary Translation and Translation Studies. Amsterdam, Rodopi (Approaches to Translation Studies 7).

HYUN, Theresa \& José LAMBERT, eds. (1994) Translation and Modernization. Vol. IV of Earl Miner and Haga Toru, general eds., ICLA 1991, Tokyo. The Force of Vision. Proceedings of the XIIIth Congress of the International Comparative Literature Association. Tokyo, University of Tokyo Press.

JANSSENS, Maddy \& Chris STEYAERT (forthcoming). "Reconsidering the Role of $A$ Translation and Language Learning Policy in An International Business Context: Beyond An Instrumental Approach."

KITTEL, Harald, Hrsg. (1988). Die literarische Übersetzung. Stand und Perspektivenihrer Erforschung. Berlin, Schmidt. (Göttinger Beiträge zur Internationalen Übersetzungsforschung, 2).

, ed. (1992). Geschichte, System, Literarische Übersetzung. Histories, Systems, Literary Translations. Berlin, Schmidt (Göttinger Beiträge zur Internationalen Übersetzungsforschung, 5).

KUSHNER, Eva, ed. (1984). Renouvellements dans la théorie de l'histoire littéraire. Montréal, McGill.

LAMBERT, José (1983a). "L'Éternelle question des frontières: littératures nationales et systèmes littéraires," in C. Angelet a.o. ed. Langue, dialecte, littérature. Études romanes à la mémoire de Hugo Plomteux. Leuven, Leuven University Press.

(1984). "Théorie littéraire, histoire littéraire, étude des traductions," in Eva Kushner, ed. (1984).

LAMBERT, José \& Hendrik VAN GORP (1985a). "On Describing Translations," in Theo Hermans, ed. The Manipulation of Literature. Essays in Translation Studies. London, Croom Helm, pp. 42-53. 
LAMBERT, José \& Hendrik VAN GORP (1985b). "Translated Literature Within European Literatures: Models for Research," in Theo Hermans, ed. Second Hand. Essays on Translated Literature. Antwerpen, Vereniging voor Algemene Literatuurwetenschap.

LAMBERT, José (1985c). "Literature in South Africa: Suggestions for Systemic Research," Journal of Literary Studies, I(2), pp. 34-42.

(1986). "Les Relations littéraires internationales comme problème de réception," in János Riesz, a.o., eds. Sensus communis. Festschrift für Henry H. H. Remak. Tübingen, Narr, pp. 49-63. Also in Euvres et critiques, XI(2) (1986), pp. 173-189.

(1988). "Twenty Years of Translation Research at the KU Leuven," in Harald Kittel, ed. Die literarische Übersetzung. Stand der Erforschung. Göttingen, Sonderforschungsbereich, pp. 122-138.

(1989b). "La Traduction, les langues et la communication de masse. Les Ambiguîtés du discours international," Target, I(2), pp. 215-237.

(1989c). "La Traduction," in Marc Angenot, Roger Bessière, Douwe Fokkema \& Eva Kushner, eds. Théorie littéraire. Paris, Presses universitaires de France, pp. 151-159.

(1989d). "L'Époque romantique en France: les genres, la traduction et l'évolution littéraire," Revue de Littérature comparée, 250, no. 2, avril-juin, pp. 165-170.

(1990a). "Le Sous-titrage et la question des traductions. Rapport sur une enquête," in R. Arntz, ed. Festschrift für Wolfram Wilss. Tübingen, Narr, pp. 228-238.

(1990b). "Translation, Translation Studies and Comparative Literature in 1989," Os Estudios literarios (entre) ciencia $e$ Hermeneutica, Actes du $1^{\text {er }}$ Congrès de la Société portugaise de Littérature comparée, Lisbonne. Lisboa, Associaçao Portuguesa de Literatura Comparada, pp. 229-239. 
(1993). "Shakespeare and French Nineteenth-centuryTheatre. A Methodological Discussion," in Dirk Delabastita \& Lieven D'hulst, eds. European Shakespeares. Shakespeare Translations in the Romantic Age. Amsterdam \& Philadelphia, Benjamins.

(1994). "Ethnolinguistic Democracy, Translation Policy and Contemporary World (Dis)Order," in Federico Eguiluz, Raquel Merino a.o. eds. Transvases culturales: Literatura, Cine, Traducción. Vitoria, Universidad del País Vasco. Departamento de Filología Inglesa y Alemana, pp. 23-36.

(forthcoming). "Translation and the Canonization of Otherness," Die Ubersetzung als Medium der Fremderfahrung. Kanoniserungsprozesse. WissenschaftlichesKolloquium Göttingen 1992. Andreas Poltermann, ed. Berlin, Schmidt. (Göttinger Beiträge zur internationalen Übersetzungsforschung)

LAMBERT, José \& André LEFEVERE (1977). "Traduction, traduction littéraire et littérature comparée," in Paul Horguelin, ed. La Traduction. Une profession. Actes du XVII Congrès de la Fédération Internationale des Traducteurs (FIT). Montréal, Conseil des Traducteurs et Interprètes du Canada.

, eds. (1993). Translation in the Development of Literatures

- Les Traductions dans le développement des littératures. Proceedings of the XIth Congress of the ICLA, Paris 1985. Frankfurt/M., Lang (Actes du XI $\mathrm{XI}^{\mathrm{e}}$ Congrès de l'AILC, vol. 7).

LEFEVERE, André (1982). "Mother Courage's Cucumbers: Text, System and Refraction in a Theory of Literature," Modern Language Studies XII(4), pp. 3-20.

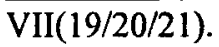

(1982). "Translation," Dispositio, Special Issue, (1992). Translation: Culture/History: A Source Book.

London \& New York, Routledge. 
LÖNKER, Fred (1990). "Systemtheoretischer Ansatz. I. Even-Zohar," Probleme der Übersetzung. Jahrbuch für internationale Germanistik, XXVI, pp. 110-114.

MOISAN, Clément (1987). Qu'est-ce que l'histoire littéraire? Paris, PUF (Littératures modernes).

(1990). L'Histoire littéraire. Paris, PUF (Que sais-je?2540).

PAGEAUX, Daniel (1994). La Littérature comparée. Paris, Colin.

POLTERMANN, Andreas (1990). "SystemtheoretischerAnsatz. Gideon Toury," Probleme der Übersetzung. Jahrbuch für internationale Germanistik, XXVI, pp. 115-123.

(1992). "Normen des literarischen Übersetzens im System der Literatur," in Kittel (1992).

PYM, Anthony (1992a). Translation and Text Transfer. Frankfurt/Main, Lang.

(1992b). "The Relationships Between Translation and Material Text Transfer," Target IV(2), pp. 171-189.

REISS, Katharina \& Hans J. VERMEER (1984). Grundlegung einer allgemeinen Translationstheorie. Tübingen, Niemeyer.

ROBYNS, Clem (1990). "The Normative Model of Twentieth Century Belles Infidèles: Detective Novels in French Translation," Target II(2).

(1992). "Towards A Sociosemiotics of Translation," Romanistische Zeitschrift für Literaturgeschichte - Cahiers d'Histoire des Littératures Romanes, 1/2, pp. 211-226.

SHAVIT, Zohar (1981). "Translation of Children's Literature as a Function of Its Position in the Literary Polysystem," in Even-Zohar and Toury (1981), pp. 171-179. 
(1986). Poetics of Children's Literature. Athens and London, University of Georgia Press.

SHEFFY, Rakefet (1990). "The Concept of Canonicity in Polysystem Theory," Poetics Todoy XI(3), pp. 511-522.

(1992). Repertoire Formation in the Canonization of Late 18th Century German Novel. Tel Aviv University. [Ph.D.Dissertation.]

SNELL-HORNBY, Mary (1988). Translation Studies. An Integrated Approach. Amsterdam \& Philadelphia, Benjamins.

(1995). "On Models and Structures and Target Text Cultures: Methods of Assessing Literary Translations," in Josep Marco Borillo, ed. La Traduccio literaria. Castello de la Plana, Universitat Jaume, pp. 43-58.

VAN COLLER, Hennie (1994). Die politieke magspel rondom taal en letterkunde in die nieuwe Suid-Afrika. ATKB-Gedenklesing. Universiteit van die Oranje-Vrystaat, 2 November 1993 (Bloemfontein, Departement Afrikaans en Nederlands).

YAHALOM, Shelly (1980). "Du non-littéraire au littéraire," Poétique, 44, pp. 406-421.

(1984). "Le Système littéraire en état de crise: contacts intersystémiques et comportement traductionnel," Poetics Today II(4), pp. 143-160.

ZIMA, Peter (1992). Komparatistik. Tübingen, Francke (UTB 1705).

ABSTRACT: Translation, Systems and Research: The Contribution of Polysystem Studies to Translation Studies - The aim of this article is not at all to examine Polysystems theory nor Polysystems research as such, but rather to discuss the impact Polysystems research has had in the development of a new discipline, i.e. Translation Studies. The ambiguous position of PS research within Translation Studies is due 
to its interdisciplinary claims and; on the other hand, to the necessity to work in a real world of disciplines where institutionalization is inevitable and even needed. The starting point of PS theory is not translation at all, but rather the dynamic functions fulfilled by translation within (inevitably) heterogeneous cultures and societies. On the basis of such hypotheses about culture(s) a rich panorama of new questions for research on translation has been worked out, as well as methodological models, and individual and collective descriptive research has been started in many countries on many cultural situations. Hence it may be accepted that descriptive research on translation would hardly have existed without the programmatic PS contribution and that the establishment of Translation Studies as an academic discipline is greatly indebted to PS. The gradual extension through various countries and disciplines (film studies, media studies, social organization, etc.) has favoured combinations with other approaches while making less clear the specific profile of the PS approach. It may be said that PS has served research as such, much more than its own sake, but wasn't this exactly the goal it wanted to achieve?

RESUMÉ: Traduction, systèmes et recherche: contribution des études polysystémiques à la traductologie - L'objectif de l'article n'est nullement d'étudier la théorie du polysystème ou les recherches polysystémiques pour elles-mêmes, mais bien plus de déterminer en quoi et comment le PS a exercé une influence dans le développement d'une discipline nouvelle, à savoir les recherches sur la traduction. La position ambiguë des recherches polysystémiques est due à leurs ambitions sur le plan de l'interdisciplinarité, mais aussi à la nécessité de fonctionner au sein d'un monde réel où l'institutionalisation est inévitable sinon même une nécessité. Le point de départ de la théorie du PS n'est point la traduction, mais bien plus l'ensemble des fonctions dynamiques remplies par les traductions dans les cultures et les sociétés, censées être hétérogènes par définition. C'est sur la base d'hypothèses de ce genre qu'un riche panorama de questions de recherche a été mis au point, ainsi que des schémas méthodologiques, puis des projets individuels et collectifs en série dans de nombreux pays et sur des situations culturelles très diverses. Il n'est pas excessif dès lors d'avancer que les DTS (Descriptive Translation Studies) n'auraient pas existé sans le programme des recherches polysystémiques, et que, plus 
globalement, les recherches sur la traduction n'auraient sans doute pas eu de statut universitaire sans le PS. L'essor du PS dans plusieurs disciplines voisines (les études cinématographiques, les recherches sur les médias, sur l'organisation sociale, etc.) a favorisé des combinaisons avec d'autres approches tout en rendant moins spécifique le profil de l'approche. On est en droit d'estimer que le PS s'est ainsi mis au service de la recherche au lieu de servir ses propres fins. En fait, tels furent exactement, semble-t-il, les objectifs officiels dès l'origine. 